\title{
Effect of Pork Rind and Soy Protein on Polony Sensory Attributes
}

\section{Crispen Mapanda ${ }^{1,2}$, Louwrens C. Hoffman ${ }^{2 *}$, Francois D Mellett ${ }^{2}$ and Nina Muller ${ }^{3}$}

${ }^{1}$ Department of Food and Nutrition, Natural Resources Development College, Chelstone, Lusaka, Zambia

${ }^{2}$ Department of Animal Sciences, Stellenbosch University, Private Bag X1, Matieland (Stellenbosch), South Africa

${ }^{3}$ Department of Food Science, Stellenbosch University, Private Bag X1, Matieland (Stellenbosch), South Africa

\begin{abstract}
This study determined whether commercially acceptable polony could be manufactured with varying quantities of chicken mechanically recovered meat (MRM), soy flour (S) and pork rind (R). The experimental design used was a two-factor, three-level factorial design, with various soy levels $(0 \%, 4 \%, 8 \%)$ and pork rind $(0 \%, 8 \%, 16 \%)$ resulting in nine treatments (R0S0, ROS4, R0S8, R8S0, R8S4, R8S8, R16S0, R16S4 and R16S8). Five treatment samples, R0S0, R0S4, R0S8, R8S0 and R8S4, which were indicated by the trained panel to have high market potential, were used to determine the degree of liking by consumers. Consumers liked the flavour and texture of treatments ROSO and ROS4 which were strongly associated with pink colour, firmness and salty taste. Treatments R0S8, R8S0 and R8S4 were preferred less, mainly because they were associated with a perceptible soy flavour, pasty texture and white fat spots. The use of soy flour and pork rind is acceptable at $<4 \%$ soy and $<8 \%$ rind.
\end{abstract}

Keywords: Pork rind; Soy flour; Chicken mechanically recovered meat

\section{Introduction}

The replacement of traditional sausage meat with chicken meat has resulted in products with new flavour and texture profiles. A chicken meat variant that is often used for this purpose is mechanically recovered meat (MRM). Chicken MRM is popular because it is cheap, rich in protein, has a fine texture and is considered healthier than traditional red meat [1]. However, literature indicates that MRM addition should be limited, as the use of high amounts of MRM could affect the quality of products negatively, resulting in products with poor texture, flavour and colour. Furthermore an increased use of MRM may in some countries result in products that are not in line with national food regulations [2]. There is thus a need to ascertain to what extent MRM can be replaced with cheaper proteins.

In South Africa there is limited scientific evidence regarding MRM replacement in sausages, except that which is found in some legal documentation. According to the South African National Standards (SANS 885) of 2003, MRM is pulped material that has been recovered by a process of mechanical separation from bone and consists predominantly of musculature tissue, collagen, marrow and fat.

Meat protein, regardless of its source, is complete, containing all the nine essential amino acids [3]. Furthermore, meat and sausages are also good sources of B complex vitamins, and all minerals except calcium. However, calcium could be slightly higher if MRM is used as protein source. The extra calcium comes from bones crushed together with the meat. In order to provide more affordable, high quality protein products, the strategy which is currently used is the partial replacement of the lean meat with non-meat ingredients. Both extenders and fillers are often used. Extenders such as soy isolate, soy concentrates, and milk powder, whey powder and egg white are used. Fillers are usually carbohydrate materials such as carrageenan and various starch materials [4]. In the current study on replacement of MRM in polony, chicken MRM was replaced with disfavoured soy flour and pork rind (also referred to as pork skin), while tapioca starch (cassava starch) was used as a filler. Polony can be classified as a finely emulsified sausage product. Emulsification involves extensive chopping (commution) of meat to produce small particles. Polony is formed by changing coarse heterogeneous meat into a homogenous meat mass consisting of dispersed water, fat and protein, which during heating is transformed into a gel [5]. Polony is regarded as a fully cooked emulsified sausage product.

Soy protein is commonly used as a replacer of meat due to its essential amino acids, whose composition (though slightly lower in quantity), is no different from that of meat. Soy also functions as a binder of polony gel contributing to water holding capacity and the emulsification of fat [6]. In terms of health benefits, soy lowers blood serum cholesterol [7-9] decreases the risk of coronary heart disease, reduces the incidence of breast and prostate cancer, and inhibits bone resorption, partially due to the presence of isoflavones [10-12].

Pork rind is also often used and is regarded as "meat" in South Africa (SANS, 2003). Pork rind, made of collagen protein, is normally added to meat formulation because it is cheaper, contributes to the total meat, as well as to the binding of water and fat in sausage [13]. The purpose of this study was to determine whether commercially acceptable polony could be manufactured with varying quantities of chicken MRM, soy flour and pork rind to a fixed protein content of $10 \%$, irrespective of fat content and without the addition of extra fat to obtain a Total Meat Equivalent (TME) of 75\%. The product quality was measured using various physical, chemical and sensory methodologies.

\section{Materials and Methods}

\section{Source and storage of ingredients}

Raw materials were obtained from local suppliers; Pork rind and MRM were obtained from Etlin International (Cape Town, Western Cape, South Africa) in a frozen form; tapioca starch and soy 1909 flour from Maccullum and Associates (Somerset West, South

*Corresonding author: Louwrens C. Hoffman, Department of Animal Sciences Stellenbosch University, Private Bag X1, Matieland 7602, (Stellenbosch), South Africa, Tel: +27 21808 4747; E-mail: Ich@sun.ac.za

Received November 18, 2014; Accepted January 08, 2014; Published January 15,2015

Citation: Mapanda C, Hoffman LC, Mellett FD, Muller N (2015) Effect of Pork Rind and Soy Protein on Polony Sensory Attributes. J Food Process Technol 6: 417. doi:10.4172/2157-7110.1000417

Copyright: (c) 2015 Mapanda C, et al. This is an open-access article distributed under the terms of the Creative Commons Attribution License, which permits unrestricted use, distribution, and reproduction in any medium, provided the original author and source are credited. 
Africa). The phosphate salt was supplied by Protea Food Division (Cape Town, South Africa). Spices and sodium chloride used bought from supermarkets in powder form. The erythrosine dye, nitrite and ascorbic acid were all supplied in powder form by Functional Foods (Stellenbosch, South Africa). Prior to utilisation, the chicken MRM and pork rind were both stored at $-18^{\circ} \mathrm{C}$. The rest of the ingredients were stored at room temperature under dry conditions.

\section{Preparation of pork rind emulsion and MRM}

Pork rind is quite tough in texture. To soften it, it was precooked before use. $7.5 \mathrm{~kg}$ of rind was cooked in $7.5 \mathrm{~kg}$ (litres) of water. The cooking time varied from 4 to $5 \mathrm{~h}$ for the three batches of pork rind prepared. After cooking, the pork rind and water mixture was reweighed and water added to make up the $15 \mathrm{~kg}$ before chopping the mixture in the bowl cutter until a fine, sticky homogenous mass called rind emulsion was formed. The rind emulsion was then allowed to cool to room temperature prior to weighing and vacuum packaging. The rind emulsion was subsequently stored at $-18^{\circ} \mathrm{C}$ until chemically analysed or used in polony processing. The only preparation done on the frozen MRM involved cutting it into smaller blocks for the purpose of easy fitting into the bowl cutter. The cut blocks of MRM were vacuum sealed and frozen until polony processing commenced.

\section{Proximate analyses of raw materials}

Only the protein-rich materials-the pork rind emulsion, soy flour and chicken MRM-were analysed for protein nitrogen, fat, moisture and ash prior to their utilisation in polony formulation. Samples were analysed in triplicate. AOAC official method number 976.05, 920.39, 934.01 and 942.05 were used for protein, fat, moisture and ash determination, respectively [14]. The average values of nitrogen obtained are shown in Table 1.

\section{Polony formulation and processing}

All nine treatments were formulated to contain $10 \%$ protein (equivalent to $48 \% \mathrm{LME}$ ). According to Table 2 the MRM, soy flour and pork rind all vary in quantities to maintain a $10 \%$ protein in the respective treatments. The percentage of water added also varied to maintain a constant product weight, while the percentage of additives was kept constant. Additives added were $8 \%$ tapioca starch, $1.8 \%$ salt, $0.016 \%$ nitrite, $0.3 \%$ phosphate, $0.05 \%$ ascorbic acid, $0.02 \%$ erythrosine dye, $0.1 \%$ each for black pepper and cayenne pepper, $0.03 \%$ ginger, $0.2 \%$ garlic, and $0.05 \%$ each for nutmeg and coriander.

Each polony sample was designed to weigh $1.5 \mathrm{~kg}$. Since 10 polony units were produced for each treatment, the total mixture of polony emulsion (meat and all ingredients added for emulsification in a bowl cutter) was $15 \mathrm{~kg}$. Each percentage indicated in Table 2 was converted into mass ( $\mathrm{kg}$ or g) by multiplying it by $15 \mathrm{~kg}$. For each treatment the percentage of rind and soy were pre-determined. So only MRM needed calculation as in the example of R0S0 (Rind $0 \%$ Soya $0 \%$ ), shown below:

\begin{tabular}{|l|c|c|c|c|c|}
\hline Ingredients & Moisture (\%) & Fat (\%) & N (\%) & $\begin{array}{c}\text { Protein } \\
(\% \mathbf{N} \times 6.25)\end{array}$ & Ash (\%) \\
\hline Chicken MRM & $67.0 \pm 0.26$ & $17.4 \pm 0.27$ & 1.9 & $12.0 \pm 0.18$ & $0.9 \pm 0.04$ \\
\hline Pork rind emulsion* & $70.4 \pm 0.33$ & $5.7 \pm 0.34$ & 2.9 & $18.1 \pm 0.14$ & $0.3 \pm 0.05$ \\
\hline Soya flour & $6.1 \pm 0.07$ & $5.6 \pm 0.11$ & 7.4 & $46.3 \pm 0.30$ & $7.7 \pm 0.21$ \\
\hline \begin{tabular}{l} 
SE: Standard error. \\
\hline
\end{tabular} \\
$\begin{array}{l}\text { *Pork rind emulsion: The ratio of pork rind and water used to make 15 kg pork rind } \\
\text { emulsion was 1:1.e }\end{array}$
\end{tabular}

Table 1: Mean proximate analysis values $( \pm S E)$ for the raw materials used in the production of the different treatments of polony.

\begin{tabular}{|l|l|l|l|l|l|l|l|l|l|}
\hline Ingredients & R0S0 & \%LME & \%EE & ROS4 & \%LME & \%EE & R0S8 & \%LME & \%EE \\
\hline MRM & 83 & 48 & 15.1 & 67.9 & 39.2 & 12.3 & 52.4 & 30.3 & 9.6 \\
\hline Pork rind & 0 & 0 & 0 & 0 & 0 & 0 & 0 & 0 & 0 \\
\hline Soy1909 & 0 & 0 & 0 & 4 & 8.8 & 0.24 & 8 & 17.7 & 0.5 \\
\hline Water & 6.6 & & & 17.9 & & & 29.1 & & \\
\hline Additives & 10.7 & & 10.7 & & & 10.7 & & \\
\hline Totals & 100 & 48 & 15.1 & 100 & 48 & 12.6 & 100 & 48 & 10.1 \\
\hline Ingredients & R8S0 & \%LME & \%EE & R8S4 & \%LME & \%EE & R8S8 & \%LME & \%EE \\
\hline MRM & 59.2 & 34 & 10.7 & 43.7 & 25.2 & 7.9 & 28.3 & 16.4 & 5.2 \\
\hline Pork rind & 8 & 14 & 0.7 & 8 & 14 & 0.7 & 8 & 13.9 & 0.7 \\
\hline Soy1909 & 0 & 0 & 0 & 4 & 8.8 & 0.2 & 8 & 17.7 & 0.5 \\
\hline Water & 22.6 & & & 33.9 & & & 45.1 & & \\
\hline Additives & 10.7 & & & 10.7 & & & 10.7 & & \\
\hline Totals & 100 & 48 & 11.4 & 100 & 48 & 8.8 & 100 & 48 & 6.4 \\
\hline Ingredients & $\mathbf{R 1 6 S 0}$ & $\%$ LME & \%EE & R16S4 & \%LME & \%EE & R16S8 & \%LME & \%EE \\
\hline MRM & 35.1 & 20.1 & 6.3 & 19.6 & 11.2 & 3.5 & 4.13 & 2.4 & 0.7 \\
\hline Pork rind & 16 & 27.9 & 1.4 & 16 & 28 & 1.4 & 16 & 27.9 & 1.4 \\
\hline Soy1909 & 0 & 0 & 0 & 4 & 8.8 & 0.2 & 8 & 17.7 & 0.5 \\
\hline Water & 38.8 & & & 50 & & & 61.2 & & \\
\hline Additives & 10.7 & & 10.7 & & & 10.7 & & \\
\hline Totals & 100 & 48 & 7.7 & 100 & 48 & 5.1 & 100 & 48 & 2.6 \\
\hline
\end{tabular}

Nine treatment combinations: ROSO- $0 \%$ pork rind and $0 \%$ soy flour; ROS $4-0 \%$ pork rind and $4 \%$ soy flour; R0S8-0\% pork rind and $8 \%$ soy flour; R8S0-8\% pork rind and $0 \%$ soy flour; R8S4-8\% pork rind and $4 \%$ soy flour; R8S8-8\% pork rind and $8 \%$ soy flour; R16S0-16\% pork rind \& $0 \%$ soy flour; R16S $8-16 \%$ pork rind \& $8 \%$ soy flour; R16S8-16\% pork rind \& $8 \%$ soy flour.

$\%$ EE: $\%$ ether extract or expected $\%$ fat content of each treatment.

\%LME: \% lean meat equivalent expected for each treatment.

Table 2: Ingredients (\%) for the formulation of each treatment with theoretical values for \%LME and \%EE

\section{Calculation of \%MRM in ROS0 treatment using protein values of Table 1}

\%Lean Meat Equivalent $(\mathrm{LME})=\%$ protein $\mathrm{x} 4.8$

Each polony to contain $10 \%$ protein, giving LME of $48 \%$

LME of MRM $=12 \%$ x $4.8=57.6 \%$

LME of soy flour $=46.4 \%$ x $4.8=222.72 \%$

LME of pork rind $=36.2 \%$ x $4.8=173.76$, where $36.2 \%$ is $18.1 \times 2$

Contribution of rind to polony $\mathrm{LME}=0 \% / 100 \times 173.76=0 \%$

Contribution of soy to polony $\mathrm{LME}=0 \% / 100 \times 222.71=0 \%$

Contribution of MRM to polony $\mathrm{LME}=48 \%-0 \%$ rind $-0 \%$ soy $=48 \%$

\section{Therefore, MRM needed $(48 \% / 57.6 \%) \times 100 \%=83 \%$}

For each treatment, a $15 \mathrm{~kg}$ emulsion (from which ten polony samples were made) was prepared using a bowl cutter with a $15 \mathrm{~kg}$ capacity (Model Manca CM21, Granollers, Barcelona, Spain,). For all the treatments, the order of adding the ingredients was the same, i.e. ingredients were added when the bowl cutter was running at low speed. After that, the speed was increased for the final chopping phase. The MRM was added and chopped first, followed by adding the salt, nitrite, the phosphate and one third of the water. This was followed by adding the rind emulsion. After that, soy flour was added into the bowl cutter and chopped for 2 min before adding spices and another third of the water. The tapioca starch was then added, after which the ascorbic acid and the last third of the water was added. Water at room temperature was used for the first five treatments because both the chicken MRM and rind emulsion were still frozen, while ice was used for the last four 
treatments after the MRM and rind emulsion had thawed. The end temperatures after chopping the polony emulsion varied between $12^{\circ} \mathrm{C}$ and $17^{\circ} \mathrm{C}$. Each emulsified treatment was tightly stuffed into $90 \mathrm{~mm}$ diameter waterproof polyethylene casings and tied off. The polonies were cooked in a steam bath for about $2 \mathrm{~h}$ to an internal temperature of $80^{\circ} \mathrm{C}$ as measured by a thermocouple. The cooked polony was then cooled in clean running water prior to storage at $4^{\circ} \mathrm{C}$ until chemical, instrumental and sensory analyses were done on the respective samples.

\section{Experimental design}

The experimental design used in the study was a two-factor, threelevel factorial design, with soy levels varying between $0 \%, 4 \%$ and $8 \%$ and pork rind varying between $0 \%, 8 \%$ and $16 \%$, resulting in nine treatments of polony, each using chicken MRM as a meat protein source (Table 2 ). The polony with $0 \%$ pork rind and $0 \%$ soy flour was regarded as the control sample. For each on the nine treatments one large batch of polony emulsion was produced according to the standardized procedure. Each treatment batch was then used to produce 10 individual polony samples, with each of these samples considered a random replication. The whole procedure (for the nine treatments) was repeated three times.

\section{Collagen analysis}

One polony sample from each of the nine treatments was selected for analysis of total collagen (hydroxyproline) from an adaptation of the procedures $[15,16]$.

Collagen analysis was conducted in two major stages: preparation of the polony filtrate, followed by the analysis of the filtrate spectrophotometrically. The details of the two stages are as follows: To determine total collagen, $4.0 \mathrm{~g}$ of homogenised polony sample from each of the nine treatments was hydrolysed by $30 \mathrm{~mL}$ of $6 \mathrm{M} \mathrm{HCl}$ in a water bath set and working at $110^{\circ} \mathrm{C}$ for $13 \mathrm{~h}$. Thereafter, the digested samples were removed from the water bath and cooled. To the cooled samples, $1.5 \mathrm{~g}$ of active carbon was added and stirred on a vortex. The carbon was then filtered out (Whatman 4 filter paper) and each sample of filtrate was collected in a $100 \mathrm{~mL}$ volumetric flask. From each of the duplicate sample filtrates, $1 \mathrm{~mL}$ was pipetted into test tubes, followed by pipetting of $1 \mathrm{~mL}$ of $10 \% \mathrm{KOH}$ into each test tube containing the sample. $\mathrm{KOH}$ was used to neutralize the $\mathrm{HCl}$ acid. A blank tube containing $2 \mathrm{~mL}$ of distilled water was also prepared. Five standard solution test tubes, each containing L-hydroxyproline concentrations of $1.25,2.5,3.75,5.0$ and $7.5 \mu \mathrm{g} / \mathrm{mL}$, were also prepared. Each test tube contained $2 \mathrm{~mL}$ of the standard solution. No KOH was added to the five standards and the blank sample. To all the test tubes with samples, including the five standards and blank sample, $1 \mathrm{~mL}$ of an oxidant solution containing chloramines- $\mathrm{T}$ was added, mixed on a vortex and allowed to stand for $20 \mathrm{~min}$ at room temperature. After $20 \mathrm{~min}, 1 \mathrm{~mL}$ of the colour reagent was added to all test tubes, followed by mixing on a vortex. The tests tubes were capped with aluminium foil and placed in a water bath at $60^{\circ} \mathrm{C}$ for $16 \mathrm{~min}$. After $16 \mathrm{~min}$, the test tubes were removed and the contents were mixed on a vortex, and then allowed to cool to room temperature until a strong aromatic pink liquid with white salt residue formed in the tubes. Test tubes with samples from treatments R0S0 to R8S8 were diluted four times and the rest were diluted five times. The transparent pink liquid in the samples, the blank and standard test tubes was pipetted into micro-cuvettes and read by an UV/visible spectrophotometer (Model CE2021) at a wavelength of $560 \mathrm{~nm}$.

\section{Instrumental colour}

A colour-guide $45^{\circ} / 0^{\circ}$ colorimeter (Cat. No: 6805 ; BYK-Gardener, USA) was used to determine the colour of the cooked polony. The apparatus was calibrated before measuring the samples from each treatment. To measure colour, three $2.5 \mathrm{~cm}$ thick slices of cooked polony were used after allowing a blooming period of $2 \mathrm{~min}$ [17]. Two readings were taken on each slice which was repeated three times for all treatments. The three slices which were used for colour measurement were immediately sealed in plastic bags and stored in a refrigerator $\left(\approx 10^{\circ} \mathrm{C}\right)$ for $10 \mathrm{~min}$ before being used for the texture measurement.

\section{Instrumental texture}

An Instron Universal Testing Machine (UTM; Model 3344) was used to perform texture profile analysis (TPA) using Bluehill software. To measure texture, $3 \times 2 \mathrm{~cm}$ diameter cores were cut out of each polony slice from each treatment, and this was replicated three times. The Instron UTM was fitted with a $5 \mathrm{kN}$ load cell and the following settings were applied: crosshead speed of $200 \mathrm{~mm} / \mathrm{min}$ and a compression of $50 \%$. The speed and compression values were adapted [18-20]. Hardness $(\mathrm{N})$, gumminess $(\mathrm{N})$ and cohesiveness (ratio) were measured.

\section{Descriptive sensory analysis}

Preliminary questionnaire development: Before conducting descriptive sensory analysis (DSA), an expert panel consisting of eight persons familiar with polony production, viewed and tasted five of the nine treatments (R0S0, R0S4, R8S0, R8S4 and R16S8) to set up an initial list of sensory descriptors. The following reference standards were also prepared to familiarize the expert panel with basic sensory notes associated with the respective ingredients: pork rind, pork rind emulsion, soy flour, corned beef, pork polony and chicken polony. The attributes agreed on for appearance were pink colour and white spots, for flavour the attributes were garlic, spicy, soy flavour and salty taste, while for texture the attributes were firmness, pastiness and fatty mouth feel.

\section{Descriptive analysis}

Nine samples, one from each treatment, were used for training the DSA panel. The same reference standards used by the expert panel were also used in the initial training of the DSA panel. Sample R0S0 served as a control sample, i.e. a fixed point to which all other samples could be compared, thereby allowing panellists to calibrate their sensory perception at the start of each training and testing session.

Six judges were trained in generic descriptive sensory analysis according to Lawless and Heymann [21]. Two training sessions were conducted on two separate days and each session lasted for $2 \mathrm{~h}$. During the training sessions the questionnaire was finalised and the judges agreed on intensity scores for the above-mentioned attributes as perceived in each of the nine treatments.

For the testing phase panellists were seated individually at sensory booths that were light and temperature controlled $\left(21^{\circ} \mathrm{C}\right)$ and fitted with the data capturing software programme Compusense five (Compusense, Guelph, Canada). An unstructured line scale, ranging from 0 to 100 was used to analyse each attribute $(0=$ zero intensity; $100=$ high intensity). A complete randomized block design was used for the testing phase where each judge received nine polony samples in each replicate session, i.e. one sample from each treatment. The sample size was a quarter slice of polony (slice thickness $=2.5 \mathrm{~cm}$ ). The samples were coded with three-digit blinding codes, presented on Petri 
dishes in a randomized order and served at room temperature $\left(21^{\circ} \mathrm{C}\right)$. Distilled water and unsalted fat free biscuits were provided as a palette cleanser between samples. The analysis was replicated four times on four consecutive days using one polony sample per replicate. Judge reproducibility was tested using Panel Check software (Panel Check software, Nofima, Norway).

\section{Consumer preference testing}

For consumer acceptability, five treatments (R0S0, R0S4, R0S8, $\mathrm{R} 8 \mathrm{~S} 0$ and R8S4) were tested using the target consumer $(\mathrm{N}=90)$. The latter five samples were indicated by the trained panel as having market potential. The nine-point hedonic scale, ranging from "like extremely" (9) to "dislike extremely" (1), was used for scoring the degree of liking of the overall flavour and texture of the five polony treatments. Each consumer was served one portion of each treatment, which was one eighth of the full slice per treatment. Samples were served on Petri dishes, coded using three-digit blinding codes, and served in a complete random order. Samples were evaluated by consumers at room temperature. Water was used for refreshing their palette during the testing of samples.

\section{Statistical procedures}

Analysis of variance (ANOVA) was performed on physical, chemical, sensory and consumer data using the General Linear Model (GLM) procedures of SAS statistical software package (Version 9.1, SAS Institute Inc., Cary, NC, USA). The Shapiro-Wilk test was performed to test for normality [22]. The Student's t-least significant difference was calculated at the $5 \%$ level to compare treatment means [23]. The proximate data were analysed separately from the abovementioned data. This was done to determine if the objective of producing treatments with $10 \%$ protein was achieved. In this instance, the Student's t-least significant difference was calculated at the $1 \%$ level to compare treatment means. Partial least squares regression (PLS) was performed using XLStats software (Addinsoft, France) to determine quality drivers of consumer liking.

\section{Results and Discussions}

\section{Protein content of polony samples}

The mean chemical values for protein of the respective treatments are presented in Table 3, whilst Table 4 indicates whether the difference between the means for protein was significant $(P<0.0001)$. The treatment which differed was R8S8 (Table 3). The pre-determined value of $10 \%$ does not lie within the confidence interval for treatment R8S8; however, it does for the other treatments. This means that the mean protein content of treatment R8S8 was higher than that of other treatments. This may have been due to problems with the raw material

\begin{tabular}{|c|c|c|}
\hline Treatment & Mean (\%) & $\begin{array}{c}\text { Simultaneous 99\% } \\
\text { confidence limits }\end{array}$ \\
\hline R8S8 & 10.5 & $10.16-10.82$ \\
\hline R16S0 & 10.3 & $9.97-10.62$ \\
\hline R8S4 & 10.3 & $9.93-10.58$ \\
\hline R8S0 & 10.2 & $9.85-10.51$ \\
\hline R0S8 & 10 & $9.71-10.37$ \\
\hline R16S8 & 10 & $9.64-10.29$ \\
\hline R0S4 & 9.9 & $9.62-10.27$ \\
\hline R16S4 & 9.8 & $9.48-10.14$ \\
\hline R0S0 & 9.7 & $9.35-10.01$ \\
\hline
\end{tabular}

Table 3: Confidence intervals for mean values of protein in nine treatments of polony.

\begin{tabular}{|c|c|c|}
\hline Parameter & F-value & $\boldsymbol{P}$-value \\
\hline Protein & 7.46 & $<0.0001$ \\
\hline Collagen & 323.81 & $<0.0001$ \\
\hline
\end{tabular}

Table 4: ANOVA results: $P$-values for protein and collagen analyses of polony samples.

\begin{tabular}{|c|c|}
\hline Treatment & Mean $(\mathbf{m g} / \mathbf{g})$ \\
\hline R16S0 & $17.9^{\mathrm{a}}$ \\
\hline R16S8 & $17.8^{\mathrm{a}}$ \\
\hline R16S4 & $17.6^{\mathrm{a}}$ \\
\hline R8S8 & $14.2^{\mathrm{b}}$ \\
\hline R8S0 & $13.9^{\mathrm{b}}$ \\
\hline R8S4 & $13.9^{\mathrm{b}}$ \\
\hline R0S0 & $9.6^{\mathrm{c}}$ \\
\hline R0S4 & $9.4^{\mathrm{c}}$ \\
\hline R0S8 & $7.2^{\mathrm{d}}$ \\
\hline LSD $(P=0.01)$ & 1.24 \\
\hline
\end{tabular}

a,b,c,dMeans with same letter are not significantly different at the $5 \%$ level of significance $(P>0.05)$.

LSD - Least significant difference

Table 5: Mean values of total collagen in nine treatments of polony.

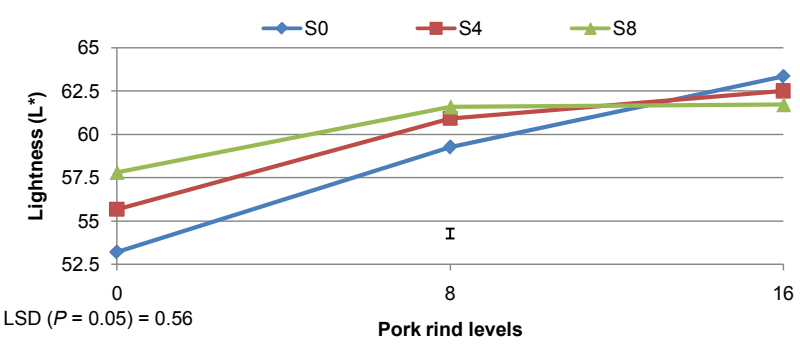

Figure 1: Mean values of instrumental lightness for nine treatments of wet polony samples manufactured with three levels of pork rind $(0,8$ and $16 \%)$ and soy levels (0, 4 and $8 \%$, shown as S0, S4 and S8).

analysis and finished product analysis. Challenges were experienced when analysing the pork rind emulsion which was extremely heterogeneous. In summary, all treatments were within range of having $10 \%$ protein except for treatment R8S8 which had slightly more.

\section{Effect of pork rind on hydroxyproline/total collagen content}

The significance $(P<0.0001)$ of the $\mathrm{F}$ value in Table 4 illustrates that some treatments were not equal in terms of total collagen content. As expected and shown in Table 5, treatments in which more rind (R16S0, R16S4 and R16S8) was used to replace MRM had the highest hydroxyproline or total collagen content, while those with less (R8S0, R8S8 and R8S8) or no added pork rind (R0S0, R0S4 and R0S8) had less total collagen. The only source of collagen for the latter three samples was the chicken MRM.

\section{Instrumental colour}

For instrumental colour, the parameters of lightness $\left(\mathrm{L}^{*}\right)$, redness $\left(a^{\star}\right)$ and yellowness $\left(b^{\star}\right)$ were determined. The effect of replacing MRM with rind and soy on $L^{*}$ is presented in Figure 1. The results show that the lowest mean value was for the control sample (R0S0) which differed significantly $(P \leq 0.05)$ from the other eight treatments. Both soy and rind proteins are white in colour. The more one of the proteins, or a combination thereof, was used to replace MRM in the respective treatments, the whiter the treatment samples became. The increase in whiteness is shown by the increase of the $L^{*}$ value in Figure 1 as 
rind and soy levels increased. These findings agree with that of Dzudie [24], who noted that sausages extended with $5,7.5$ and $10 \%$ common bean flour $(\mathrm{CBF})$ were lighter than the control, which had no CBF. In another study, Fojtik and Mandigo [25] used two different levels of 10 and $20 \%$ pork skins (pork rinds) in combination with higher quantities of water in fresh pork sausages. Their results also showed that pork sausages became lighter, mainly due to the dilution of lean meat blood pigments by increased pork skin and water levels. Dingstad [26] noted in frankfurters that lightness can be regarded as the main attribute driving consumer acceptability. They observed that at least $60 \%$ of consumers were willing to buy sausage when $\mathrm{L}^{*}$ was between 62.3 and 68.5 .

The mean values of redness $\left(\mathrm{a}^{*}\right)$ decreased with an increase in both rind and soy proteins (Figure 2). Chicken MRM contains red pigments of blood (myoglobin and haemoglobin). The replacement of MRM with white proteins (rind and soy) reduced the red colour of the polony treatments. These findings agree with who observed that samples of sausages substituted with 7.5 and $10 \%$ common bean flour had a lower degree of redness. Similarly, Akesowan found that the use of $1.5 \%$ or more soy protein isolate caused pork sausages to be less red. However, the current results contradict what Fojtik and Mandigo found. In the latter study, the use of higher levels of pork skin in sausage formulation did not affect redness.

The results for yellowness $\left(b^{*}\right)$ are shown in Figure 3. Generally, the mean values of $b^{*}$ for samples with $8 \%$ soy (S8) increased, while samples with $0 \%(\mathrm{~S} 0)$ and $4 \%$ soy (S4) decreased up to the level of $8 \%$ rind. However, the $\mathrm{b}^{*}$ value of S4 increased slightly at the level of $16 \%$ rind while that of S0 did not increase significantly. These results show that soy increased yellowness in the treatments where it was added. This was probably due to the soy flour which was slightly yellow in colour. In a study by Akesowan, in which $1.5 \%$ or more soy protein was used to make pork sausages, it was observed that the sausages became more yellow. Similarly, Dzudie found that samples were more

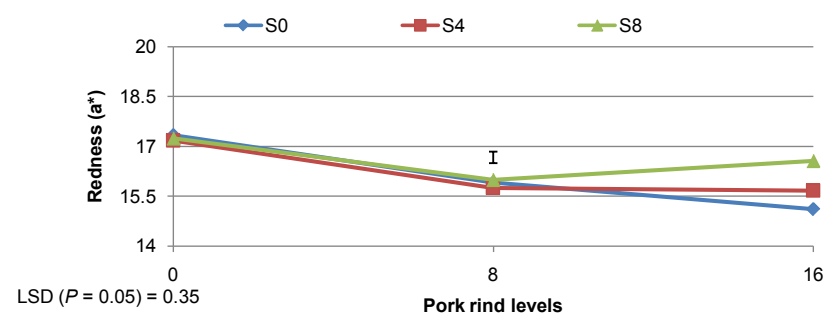

Figure 2: Mean values of instrumental redness for nine treatments of wet polony samples manufactured with three levels of pork rind $(0,8$ and $16 \%$ ) and soy levels $(0,4$ and $8 \%$, shown as S0, S4 and S8).

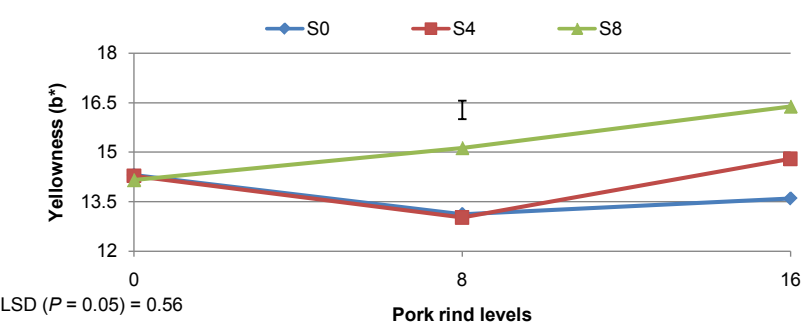

Figure 3: Mean values of instrumental yellowness for nine treatments of we polony samples made with three levels of pork rind (0,8 and 16\%) and soy levels $(0,4$ and $8 \%$, shown as S0, S4 and S8).

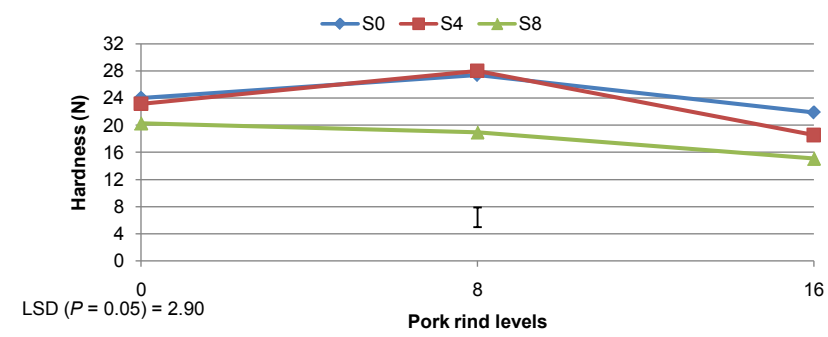

Figure 4: Mean values of instrumental hardness in nine treatments of wet polony samples made with three levels of pork rind (0, 8 and 16\%) and soy levels (0, 4 and $8 \%$, shown as S0, S4 and S8).

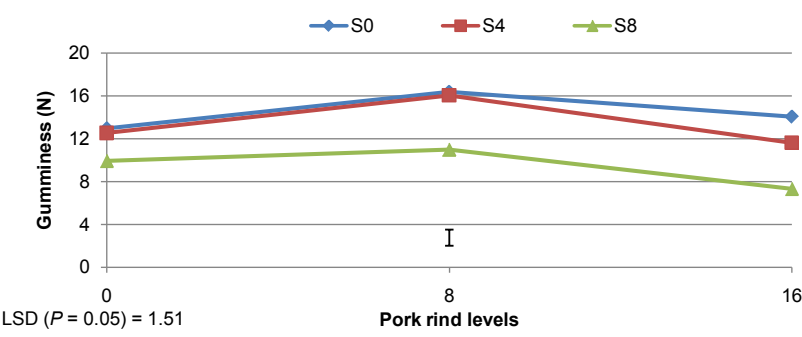

Figure 5: Mean values of instrumental gumminess in nine treatments of wet polony samples with three levels of pork rind $(0,8$ and $16 \%)$ and soy levels $(0,4$ and $8 \%$, shown as S0, S4 and S8).

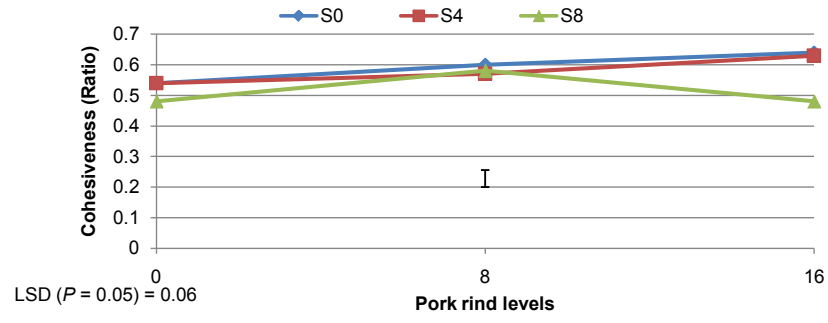

Figure 6: Mean values of instrumental cohesiveness in nine treatments of wet polony samples made with three levels of pork rind $(0,8$ and 16\%) and soy levels (0, 4 and $8 \%$, shown as S0, S4 and S8).

yellow when levels of 7.5 and $10 \%$ of common bean flour were used in extending sausages.

\section{Instrumental texture}

The results shown in Figure 4 indicate that the replacement of MRM with rind levels of up to $8 \%$ and soy levels of up to $4 \%$ increased the hardness (firmness) of the polony treatments, while treatments with $8 \%$ soy were softer at all levels of rind. Similar results were obtained for gumminess (Figure 5). These results show that good quality polony with acceptable hardness can be obtained with up to $4 \%$ soy and $8 \%$ rind. Beyond $4 \%$ of soy flour, the products become softer and sticky. According to Chambers and Bowers [27], hardness is the most important attribute to consumers because it determines the commercial value of the processed meat products. Approximately $60 \%$ consumers will be willing to buy a sausage with a hardness of $47.3 \mathrm{~N}$ and higher (Dingstad). However, higher values for the parameter do not necessarily mean better quality. There is a cut-off point above which the texture of comminuted meat products would be unacceptable [28]. According to this finding, all the polony treatments made in this project might not be very acceptable to consumers, as most of the mean values for hardness were below $47.3 \mathrm{~N}$. 
According to Figure 6, all treatments with up to $8 \%$ pork rind, did not differ $(P>0.05)$ for the attribute of cohesiveness, while at the $16 \%$ rind level, the mean cohesiveness value of S8 was reduced significantly $(P \leq 0.05)$. In general, these results show that the replacement of MRM with soy protein increased the cohesiveness of polony treatments at all levels of rind, except for products with $8 \%$ soy (S8), which decreased at the $16 \%$ level of rind. These findings show that the addition of binding aids such as soy and rind improve cohesiveness, as long as too much is not used (Trock). Chin [29] established that the use of incremental levels of soy protein below 3\% decreased the cohesiveness of low-fat meat products. The current results disagree with the findings of Chin as some of the treatments of polony in which only soy protein was used, for instance at the level of $4 \%$, showed that cohesiveness increased. A possible explanation might be the difference in the fat content of the products used in their study and in the current study.

\section{Sensory profile}

The effect of replacing MRM with soy flour and pork rind significantly $(P \leq 0.05)$ decreased the typical pink colour of all polony treatments compared to the control sample R0S0 (Figure 7). However, samples R0S4 and R0S8 did not differ $(P>0.05)$ from each other. Similarly, samples R8S8 and R16S0 did not differ significantly from each other. For white spots, samples R0S4 and R0S8 did not differ $(P>0.05)$ from the control sample, while the rest differed significantly from the control sample $(P \leq 0.05)$. The present findings for pink colour are consistent with Abiola and Adegbaju [30], who reported that, when pork back fat was replaced with rind levels of $0,33,66$ and $100 \%$, the colour of pork sausages decreased correspondingly. The negative effect of MRM replacement with rind and soy on the pink colour of polony can be counteracted by adding more dye during the emulsification stage. In South Africa, dyes such as erythrosine BS can be added to enhance the pink colour of polony up to the maximum level of $30 \mathrm{mg} /$ $\mathrm{kg}$ of the product, Department of Health [31].

In the treatments where rind was added (R8S0, R8S4, R8S8, R16S0, R16S4 and R16S8), white spots were observed. The white spots were actual pieces of rind which resulted from incomplete emulsification of the pork rind emulsion by the bowl cutter. This negative attribute could be rectified by extensive chopping of the raw batter of the treatments containing pork rind.

Figure 8 shows that the mean values of both salty taste and garlic flavour decreased compared to that of the control sample, as more MRM was being replaced by increasing levels of soy flour and pork rind, while the mean values of soy flavour increased. Matulis [32] established that the flavours produced by soy proteins in frankfurters (soy levels used ranged from 0 to $3 \%$ ) masked the intensity of other

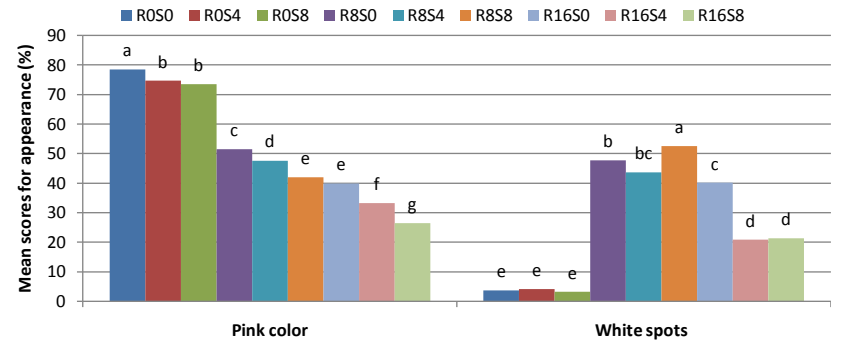

Figure 7: Mean scores for pink colour and white spots of nine treatments of polony manufactured with three levels of pork rind (0, 8 and $16 \%)$ and soya $(0,4$ and $8 \%)$. Means within each sensory attribute with the same letter do not differ significantly $(P>0.05)$.

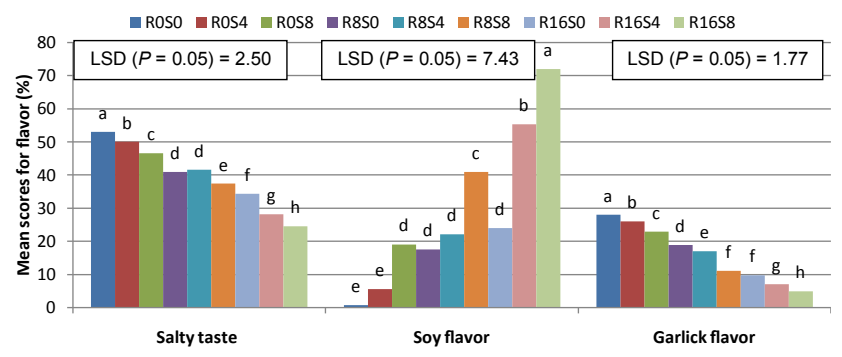

Figure 8: Mean scores for salty taste, soy flavour and white garlic flavour of nine treatments of polony manufactured with three levels of pork rind $(0,8$ and $16 \%)$ and soy $(0,4$ and $8 \%)$. Means within each sensory attribute with the same letter do not differ significantly $(P>0.05)$

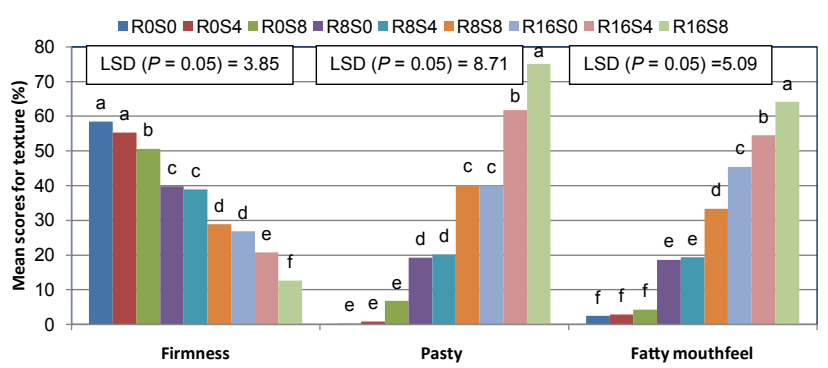

Figure 9: Mean scores for firmness, pasty and fatty mouth feel of nine treatments of polony manufactured with three levels of pork rind $(0,8$ and $16 \%)$ and soy $(0,4$ and $8 \%)$. Means within each sensory attribute with the same letter do not differ significantly $(P>0.05)$.

flavours. Similarly, Chin established that low levels $(<3 \%)$ of soy protein decreased juiciness and saltiness in low-fat meat products. For the samples which had no soy added to the formula (R0S0, R8S0 and R16S0), the scores for soy flavour were expected to be zero, but this was not the case. The low intensity scores for soy flavour in samples R8S0 $(<20)$ and R16S0 $(<25)$ could possibly be attributed to a synergistic flavour effect of the other ingredients, this tendency, however, requires further clarification.

Since the reduction of salty taste and garlic flavour is undesirable in polony substituted with soy and rind, more salt and garlic could be added to formulations of polony to counteract the negative flavour effect of meat substitutes. In the present study, the amount of salt which was added to all treatments was $1.8 \%$, while the levels of spices ranged from $0.05 \%$ to $0.2 \%$. Salt could be increased up to 2 or $3 \%$ [33], however, increased levels of $\mathrm{Na}$ need to be researched cognisance of the fact that there are currently regulations in place to limit the $\mathrm{Na}$ content of processed foods, Department of Health, 2012. Garlic can be added up to $3-5 \mathrm{~g} / \mathrm{kg}$ (equivalent to $0.3-0.5 \%$ ) in order to enhance the flavour of polony substituted with rind and soy flour, Feiner.

For sensory texture, the attributes analysed were firmness, pastiness and fatty mouth feel (Figure 9). All treatments decreased in sensory firmness due to an increase of soy and rind proteins, and all treatment mean values differed $(\mathrm{P} \leq 0.05)$ from that of the control sample, except for R0S4. For both pastiness and fatty mouth feel, the mean scores for these two texture attributes increased in all samples compared to that of the control treatment. However, for both pasty and fatty mouth feel, the mean scores for samples R0S4 and R0S8 did not differ $(\mathrm{P}>0.05)$ from that of the control, while the rest did. Feiner highlighted that the replacing of lean meat with soy protein and water, as was done in the present study, affects texture and firmness because the replaced meat 
proteins contribute positively to the named parameters. In Figure 9 it can clearly be seen that an increased replacement of chicken MRM with pork rind and soy flour reduced firmness and increased the sensory textural attributes of pastiness and fatty mouth feel in all the polony treatments, except for the control sample.

\section{Consumer acceptability}

Samples R0S0 and R0S4 were the most preferred samples for its flavour and texture, while sample R0S8 was the least preferred and had an extremely low degree of acceptability in terms of flavour and texture (Figure 10). The other two samples were intermediately preferred.

The potential quality drivers of consumer preference are indicated in the PLS plot (Figure 11). The sensory attributes, i.e. a distinctive pink colour, moderate firm texture and salty taste associated with the two preferred samples, R0S0 with zero rind and soy and R0S4 with low

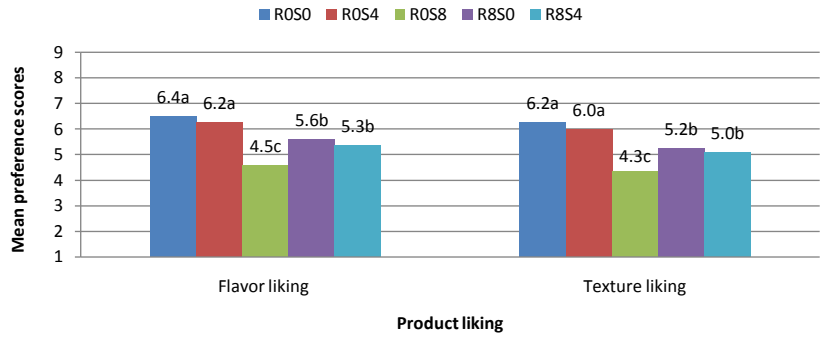

Figure 10: Mean product liking scores for flavour and texture as indicated by 90 consumers, where ROS0-0\% rind and $0 \%$ soy flour; ROS $4-0 \%$ rind and $4 \%$ soy flour; ROS $8-0 \%$ rind and $8 \%$ soy flour; R8S0-8\% rind and $0 \%$ soy flour; R8S4-8\% rind and $4 \%$ soy flour [Flavour LSD $(P=0.05)=0.41$, Texture LSD $(P=0.05)=0.42]$. Means within each attribute with the same letter do not differ significantly $(P>0.05)$

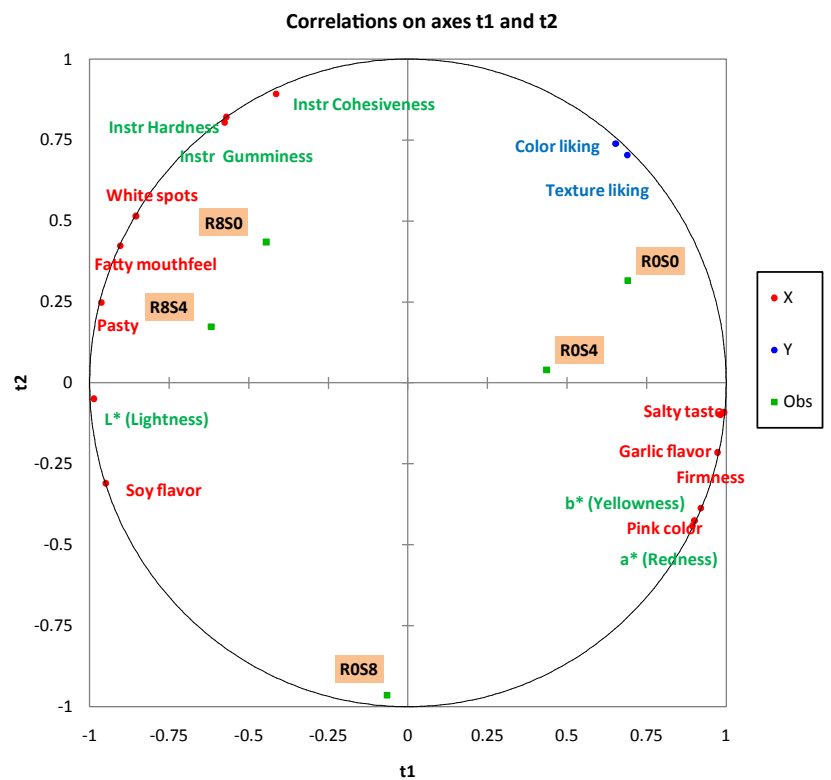

Figure 11: PLS plot illustrating the quality drivers of consumer preference of five polony treatments (ROSO with $0 \%$ rind and $0 \%$ soy flour; ROS 4 with $0 \%$ rind and $4 \%$ soy flour; R0S 8 with $0 \%$ rind and $8 \%$ soy flour; R8S0 with $8 \%$ rind and $0 \%$ soy flour; R8S4 with $8 \%$ rind and $4 \%$ soy flour). The X-matrix constitutes the sensory and physical attributes and the $Y$-matrix the two degree of attributes. The degree of liking attributes (Flavor and Texture) are indicated in BLUE, sensory attributes in RED and instrumentally measured attributes (Color \& Texture) in GREEN. levels of soy. R80S0 and R8S4, both formulated with moderate levels of rind and zero or low levels of soy, illustrated low levels of acceptability, mainly due to the visible white spots, fatty mouth feel. According to Figure 11 sample R0S8 was liked least and regarded as unacceptable, probably due to the low intensities of the positive quality attributes indicated on the right side of the PLS plot and higher intensity levels of the negative quality attributes on the right side of the plot. This tendency of consumers to prefer or accept products, in which no or limited substitution of meat was made, has been observed by other researchers. For instance, Abiola and Adegbaju found that the acceptability of pork sausages with $0 \%$ rind was higher than that of other batches in which pork rind levels of 33, 66 and $100 \%$ were used.

\section{Conclusion}

This study investigated the effect of replacing MRM with pork rind and soy flour protein on the sensory, chemical and physical attributes of polony as well as the consumer acceptability. It was observed that the replacement of MRM with higher levels of pork rind (16\%) and soy flour (4 and 8\%) resulted in polony treatments which were very light in colour, poor in texture and flavour, while those with lower levels of pork rind $(\leq 8 \%)$ and soy flour $(\leq 4 \%)$, including the control sample, illustrated better texture, colour and flavour attributes. The results also indicated that the treatments with lower levels of pork rind and soy flour, including the control, were more acceptable from a consumer point of view than those with higher levels MRM replacers.

It is thus concluded that commercially acceptable polony could be manufactured with varying quantities of chicken MRM, a maximum of $4 \%$ soy flour and $8 \%$ pork rind to a fixed protein content of $10 \%$, irrespective of fat content and without the addition of extra fat to obtain a Total Meat Equivalent (TME) of 75\%. This type of polony formulation should be cheaper and more affordable for the lower income groups and ensure sufficient protein consumption and aid in enhancing food security within this group.

\section{References}

1. Crosland AR, Patterson RLS, Higman RC, Steward CA, Hargin KD, et.al (1995) Investigation of methods to detect mechanically recovered meat in meat products. I. Chemical composition. Meat Science 40: 289-302.

2. Heinz G, Hautzinger $P$ (2007) Meat processing technology for small- to medium-scale producers. FAO RAP Publication.

3. Weiss J, Gibis M, Schuh V, Salminen H (2010) Advances in ingredient and processing systems for meat and meat products. Meat Science 86: 196-213.

4. Subba D (1998) Fundamental differences between oriental and western technology of meat products. Tribhuvan University Journal 21: 121-127.

5. Giese J (1992) Developing low-fat meat products. Food Technology 46: 100-

6. Akesowan A (2008) Effect of soy protein isolate on quality of light pork sausages containing konjak flour. African Journal of Biotechnology 7: 4586-4590.

7. Anderson J, Johnstone W BM, Cook-Newl ME (1995) Meta-analysis of the effect of soy protein intake on serum lipid. New England Journal of Medicine 333: $276-282$.

8. Messina M (1999) Legumes and soybeans: overview of their nutritional profiles and health effects. American Journal of Clinical Nutrition 70: 439S-450S.

9. Lee K, Brennand PC (2005) Physicochemical, textural and sensory properties of a fried cookie system containing soy protein isolate. International Journal of Food Science and Technology 40: 501-508.

10. Kennedy AR (1995) The evidence of soybean products as cancer preventing agents. Journal of Nutrition 125: 733S-743S

11. Gallagher JC, Rafferty K, Haynatzka V, Wilson W (2000) The effect of soy: protein on bone metabolism. Journal of Nutrition 130: 667S-673S. 
Citation: Mapanda C, Hoffman LC, Mellett FD, Muller N (2015) Effect of Pork Rind and Soy Protein on Polony Sensory Attributes. J Food Process Technol 6: 417. doi:10.4172/2157-7110.1000417

12. Trock B, Butler LW, Clarke R, Hilakivi-Clarke L (2000) Meta-analysis of soy intake and breast cancer risk. Journal of Nutrition 130: 690S-691S.

13. Ranken MD (2000) Handbook of meat product technology: Blackwell Science Ltd, London, United Kingdom.

14. AOAC (2002) Official method of analysis (1 $7^{\text {th }}$ Edition). VA Association of Official Analytical Chemists, Inc.

15. Cross HR, Carpenter ZL, Smith GC (1973) Effect of intramuscular collagen and elastin on bovine muscle tenderness. Journal of Food Science 38: 998-1003.

16. Hill F (1966) The solubility of intramuscular collagen in meat animals of various ages. Journal of Food Science 31: 161-166.

17. Yang H, Choi J, Park G, Joo S (2007) Textural and sensory properties of low fat pork sausages with added hydrated oatmeal and tofu as texture-modifying agents. Meat Science 75: 283-289.

18. Flores M, Giner E, Fiszman SM, Salvador A, Flores J (2007) Effect of a new emulsifier containing stearoyl-2-lactylate and carrageenan on the functionality of meat emulsions systems. Meat Science 76: 9-18.

19. Caceres E, Garcia ML, Toro J, Selgas MD (2004) The effect of fructooligosaccharides on the sensory characteristics of cooked sausages. Meat Science 68: 87-96.

20. Cierach M, Modzelewska-Kapitula M, Szacilo K (2009) The influence of carrageenan on the properties of low-fat frankfurters. Meat Science 82: 295-

21. Lawless HT, Heymann H (2010) Sensory evaluation of food principles and practises. Springer, New York, USA

22. Shapiro SS, Wilk MB (1965) An analysis of variance test for normality (complete samples). Biometrika 52: 591-611.

23. Ott RL (1998) An introduction to statistical methods and data analysis. Duxbury Press, California, USA.
24. Dzudie T, Scher T, Hardy J (2002) Common bean flour as an extender in beef sausages. Journal of Food Engineering 52: 143-147.

25. Fotjik T, Mandigo WR (1998) Utilisation of raw pork skins in reduced fat fresh pork sausage. Nebraska Swine Report Pp. 44

26. Dingstad GI, Kubberod E, Næs T, Egelandsdal B (2005) Critical quality constraints of sensory attributes in frankfurters type sausages to be applied to optimisation models. LWT-Food Science and Technology 38: 665-676.

27. Chambers EN, Bowers JR (1993) Consumer perception of sensory quality in muscle foods. Journal of Food Technology 47: 116-120.

28. Yu SY, Yeang SB (1993) Effects of type of starch on the quality of fish balls In Development of food science and technology in South-East Asia, Indonesia IPB Press.

29. Chin KB, Keeton TJ, Longnecker MT, Lamkey WJ (1999) Utilisation of soy protein isolate and konjac blends in low-fat bologna (model system). Meat Science 53: 45-57.

30. Abiola SS, Adegbaju SW (2001) Effect of substituting pork back fat with rind on quality characteristics of pork sausage. Meat Science 58: 409-412.

31. Department of Health (2012) Regulation relating to the reduction of sodium in certain foodstuffs Government Notice R.533 of Food, Cosmetics and Disinfectant Act of 1972 (Act No. 54), South Africa.

32. Matulis RJ, McKeith FK, Sutherland JW, Brewer MS (1995) Sensory characteristics of frankfurters as affected by fat, salt and $\mathrm{pH}$. Journal of Food Science 60: 42-47.

33. Feiner G (2006) Meat products handbook Practical science and technology: Woodhead Publishing Ltd, Cambridge, United Kingdom. 